\title{
Algılanan Örgütsel Desteğin Çalışanların İşe Yabancılaşması ve İşten Ayrılma Niyetine Etkisi Üzerine Bir Araştırma
}

\section{A Research on The Effects of Perceived Organizational Support on The Work Alienation and Turnover Intentions of Employees}

Mutlu Tokmak ${ }^{\mathrm{a}, *}$

a J. Yzb. Dr, Jandarma ve Sahil Güvenlik Akademisi, Jandarma ve Sahil Güvenlik Fakültesi, Sosyal Bilimler Bölümü, 06000, Ankara / Türkiye ORCID: 0000-0002-7428-1322

\section{MAKALE BILGİSI}

\section{Makale Geçmişi:}

Başvuru tarihi: 01 Eylül 2019

Düzeltme tarihi: 23 Aralık 2019

Kabul tarihi: 08 Ocak 2020

Anahtar Kelimeler:
Algılanan Örgütsel Destek,
İșe Yabancılaşma,
İșten Ayrılma Niyeti

A R T I CLE IN F O

\section{Article history:}

Received 01 September 2019

Received in revised form 23 December 2019

Accepted 08 January 2020

\section{Keywords:}

Organizational Support Perception,

Work Alienation,

Turnover Intentions

\section{ÖZ}

Bu çalışmanın amacı, çalışanların algıladıkları örgütsel desteğin işe yabancılaşma ve işten ayrılma niyeti üzerine etkisinin belirlenmesidir. Araştırmada betimsel istatistik analizi, korelasyon ve regresyon analizleri gerçekleştirilmiştir. Korelâsyon analizleri neticesinde, örgütsel destek algısı ile işe yabancılaşma arasında negatif yönlü 0.432 oranında orta düzeyde ilişki tespit edilmiştir. Algılanan örgütsel destek ile işten ayrılma niyeti arasında anlamlı bir ilişki tespit edilememiştir. İşe yabancılaşma ile işten ayrılma niyeti arasında pozitif yönlü ve anlamlı 0.674 oranında orta düzeyde korelâsyon olduğu belirlenmiștir. Basit doğrusal regresyon analizleri neticesinde, algılanan örgütsel desteğin işe yabancılaşma üzerinde 0.187 oranında negatif etkisinin olduğu belirlenmiştir. Algılanan örgütsel desteğin işten ayrılma niyeti üzerinde istatistiksel olarak anlamlı bir etkisi saptanmamıştır. İşe yabancılaşmanın, işten ayrılma niyeti üzerinde ise 0.454 oranında pozitif etkisi olduğu tespit edilmiştir.

\section{Giriş}

Günümüz iş dünyasında teknolojinin gelişmesi ile birlikte rekabet hızı da artmıştır. Rakipleri ile kıyasıya rekabet içerisinde olan işletmelerin en önemli kaynağını beşeri sermayesi olan çalışanlar oluşturmaktadır. İşletmelerin beşeri sermayesi olan işgörenlerinden etkin ve verimli bir şekilde yararlanabilmeleri için onlara her konuda destek olmaları gerekmektedir. Nitelikli personele sahip olan, çalışanlarından verimli ve etkin bir şekilde yararlanabilen işletmelerin rekabet avantajı sağlaması rakiplerine kıyasla daha kolaydır. Çalışanların kurumları için var gücüyle çalışmalarında, örgütsel desteğin etkisi kaçınılmazdır. Gerek ücret, çalışma koşulları, ödüllendirme gibi maddi destekler, gerekse kariyer olanakları, iş ve aile yaşamlarına katkı sağlayan maddi olmayan konularda sağlanan destekler işgörenlerin kurumları için daha özverili bir şekilde çalışmalarını sağlayacaktır.

İşgörenler bazı sebeplerden dolayı kurumlarına karşı kendilerini yabanc1 hissetmektedirler. Bu gibi durumlarda

\footnotetext{
* Sorumlu yazar/Corresponding author.

e-posta: mutlu-tokmak@hotmail.com
} 
mevcut kurumlarında çalışmaktan memnun olmazlar. Kendilerini çalıştıkları işe karşı yabancı hisseden personelin etkili ve verimli olması da mümkün değildir. Kurum yöneticilerinin çalışanların işe yabancılaşmalarını engelleyecek önlemler almaları, onları tekrar kazanarak işletme içerisinde çalışmaktan memnun olacak düzeye getirmeleri gerekmektedir. Aksi takdirde çalışanların yaptıkları işe yabancılaşmaları sonucunda mevcut kurumlarında çalışma istekleri de azalacaktır. Bu durum zamanla çalıșanların işten ayrılma isteklerinin artmasına neden olacaktır. İşletmelerde çalışanların sürekli işten ayrılma niyeti personel devir hızını arttıracaktır. Personel devir hızının yüksek olduğu kurumların başarılı olması ise mümkün değildir. $\mathrm{Bu}$ çalışmanın motivasyonu, örgüt tarafından çalışanlara yönelik sağlanan desteğin işe yabancılaşma ve işten ayrılma niyeti üzerindeki etkisini ortaya koymaktır.

$\mathrm{Bu}$ çalışma, çalışanların işe yabancılaşma ve işten ayrılma niyetini azaltmaya yönelik işletmeler tarafından alınması gereken önlemler kapsamında, örgüt tarafından sağlanacak desteğin etkisini ortaya koyması açısından önem arz etmektedir.

Bu çalışmada, Bursa ili Karacabey ilçesinde faaliyet gösteren çalışanların algıladıkları örgütsel desteğin işe yabancılaşma ve işten ayrılma niyeti üzerindeki etkisi araştırılmaktadır. Bu kapsamda çalışanların algıladıkları örgütsel destek seviyesi, işe yabancılaşma düzeyleri ve işten ayrılma niyetleri arasındaki ilişkiler ortaya konulmaya çalışılmıştır. Araştırmada belirlenen amaçları gerçekleştirmek için alan araştırması yapılmış ve elde edilen veriler istatistiksel hesaplamalar sonucunda aktarılmaya çalışılmıştır. $\mathrm{Bu}$ çalışmanın konu ile ilgili yapılan diğer araştırmalara ve örgütlere katkı sunacağı düşünülmektedir.

\section{Kavramsal Çerçeve}

\subsection{Algılanan Örgütsel Destek Kavramı}

Örgütsel destek algısı kavramı literatürde ilk kez Eisenberger vd. (1986) tarafindan ortaya atılmıştır. Eisenberger vd. (1986: 503)'e göre işgörenler, çalıştıkları kuruma kişisel özellikler atfederek algı oluşturma eğilimindedirler. Örgütsel desteğin, sosyal, fizyolojik ve psikolojik özellikleri vardır. Örgütsel destek, çalışan ve örgüt arasındaki karşılıklı ilişki olarak ortaya çıkmaktadır. Schaffer ve Harrison (2001: 102)' a göre örgütsel destek, "örgüt tarafından çalışanların bağlılıklarına güvenme" olarak tanımlanmaktadır. Algılanan örgütsel destek, çalışanların örgütlerine karşı olan bağlılıklarını, örgütün çalışanlar tarafından sağlanan katkılara değer vermesi ve onların iş ortamındaki mutlulukları ile ilgilerini kapsayan bir kavramdır (Zagenczyk, 2006: 13). Meyer vd. (1990:716)'ya göre örgütsel destek, çalışanların haklarının korunması, örgüte olan desteklerinden dolayı kurum tarafindan itibar görmesi ve değer verilmesini kapsamaktadır. $\mathrm{Bu}$ kapsamda, çalışanların kurum içerisinde algıladığı desteğe dayalı olarak sergiledikleri davranışlar algılanan örgütsel destek olarak ifade edilmektedir. (Kurtessis vd., 2015:2)'ye göre algılanan örgütsel destek, işgörenlerin kuruma kazandırdıkları çerçevesinde kurumun işgörene gösterdiği değer karşısında işgörenin geliştirdiği algıyı ifade etmektedir. Algılanan örgütsel destekte çalışanlar örgüt için sağladıkları katkılar sonucunda örgüt tarafindan ödüllendirmeyi beklemektedirler.
Örgüt tarafından çalışanlara sağlanan desteğin algılanan örgütsel destek olarak ifade edilmesindeki temel etken, aynı kurumda aynı işi yapan ve örgüt tarafından aynı kural ve prosedürlere bağlı olan kişilerin algıladıkları desteğin farklı olabileceği olgusudur. Algılanan örgütsel destek de, kurumun çalışanlar için ne kadar destek sağladığından çok, çalışanların örgütün kendisini ne kadar desteklediği algısı daha çok belirleyici olmaktadır (Kerse ve Karabey, 2017: 377). İşgörenlerin algıladıkları örgütsel destek sayesinde çalışanların güven duygu artmaktadır ve kurumlarının her zaman yanında oldukları düşüncesine sahiptirler (Özdevecioğlu, 2003: 116).

Örgütsel destek algısı ile ilgili literatürde iki farklı unsur ele alınmaktadır. İlki, örgütün çalışanlarına değer vermesini ve onu tanımasını, ücret, kıdem arttırma, ödül, yardım ve diğer maddi unsurlarda destek sağlanmasını içermektedir. Bu özelliği ile örgütsel destek, çalışanların belirlenen hedefleri yerine getirmeleri karşılığında ödüllendirileceği konusunda çalışan beklentilerini yükseltmeyi amaçlamaktadır. İkincisi ise, örgütsel desteğin çalışanların sosyal ve duygusal konulardaki mutluluğu ile ilgilendiğidir. Bu konuda iş ile ilgili faaliyetlerden farklı olarak, kişinin ailesi ve sosyal çevresi ile zaman harcaması konusunda uygulanan politikaları kapsamaktadır. $\mathrm{Bu}$ unsur sosyal mübadele yaklaşımı ile açıklanmaktadır. Çalışan ve işveren arasındaki ilişkilerde karşılıklılık esasına dayalı olarak kazan-kazan prensibi ön planda tutulmaktadır. (Rhoades vd., 2001: 828; Aselage ve Eisenberger, 2003: 494). Çalışanlara öncelikle maddi konularda destek sağlanması çalışanları istenilen ölçüde mutlu etmemektedir. Çalışanların daha fazla para kazanma duygusu yeterince tatmin edilemediğinde yapılan işten soğuma ve geri çekilme başlamaktadır. Çalışanlara manevi yönden değer verilmesi çalışanların kendilerini önemli hissetmelerine, özgüvenlerinin gelişmesine ve kendi yeteneklerinin farkına varmalarına yardımcı olmaktadır. Maddi unsurlardan ziyade manevi unsurların örgütsel destek algılamalarında daha etkili olduğu belirtilmektedir. (Aselage ve Eisenberger, 2003: 493).

Algılanan örgütsel desteğin arttırılmasında; kurumun çalışanlarına verdiği değerin hissedilmesi, örgüt içerisindeki iletişim kanallarının açık olması, kurum içerisinde uygulanan kurallarda ve politikalarda adil ve tutarlı olunmas1, örgütsel güven ikliminin oluşturulmas1, gönüllülüğün ön planda tutulması, karşılıklılık ilkesine önem verilmesi ve duygusal bağlılık gibi konular önem taşımaktadır (Rottinghaus vd., 2009: 144). Kaplan (2010: 41)' a göre algılanan örgütsel desteğin arttırılması için; yönetici ve çalışan arasında kalitesi bir iletişimin sağlanması, yeterli maaş ödemesi, çalışanların gelişimi için eğitim imkânlarının sunulması, terfi ve teşvik gibi ödüllendirmeler, işletme hedeflerinin belirlenmesinde çalışanların katılımı, uygun iş davranışları konusunda rehberlik hizmetlerinin verilmesi, örgütsel adalet gibi konulara işletme yöneticileri tarafindan önem verilmesi gerekmektedir.

\section{2. İşe Yabancılaşma}

İşe yabancılaşma, çalışanların yaptıkları iş ile ilgilerinin azaldığ , yaptıkları işe çok az enerji harcadıkları ve ödüllere öncelik verdikleri tutum ve davranışlar olarak değerlendirilmektedir. İşe yabancılaşma tutumu içerisinde olan çalışanlardan yeterli performans beklenmemektedir (Agarwal, 1993: 723). Hirschfeld ve Feild (2000: 790), işe 
yabancılaşmayı, çalışanların iş dünyası ile bağlarını kopardıkları ve çalışma yaşamındaki rollerine bağlılıklarının azaldığ 1 bir tutum olarak değerlendirmektedirler. Nair ve Vohra (2012: 25) işe yabancılaşmayı, "işgörenlerin yaptıkları iş ile bağlantılarını kesmesi" şeklinde tanımlamışlardır. İşe yabancılaşma sürecinde çalışanlar iş yaşamı ile ilgili hayal kırıklığı içerisindedirler. Bu durum yöneticileri ve çalışma arkadaşları ile olan ilişkilerinde tatminsizlik hissi yaratmaktadır. İşe yabancılaşma duygusu içerisinde olan çalışanlar hem üretim sürecinden hem de çevrelerinden uzaklaşmaktadırlar (Aiken ve Hage, 1966: 497; Banai ve Reisel, 2007: 466). İşe yabancılaşan çalışanlar yaptıkları işin kişisel ihtiyaçlarına ve belirledikleri hedeflere ulaşmada kendilerine bir katkı sağlamadığı düşüncesindedirler. Yaptıkları işi kendi gelişimleri ve içsel ihtiyaçlarını karşılamaktan ziyade zorunlu olarak ve dışsal ihtiyaçlarını karşılamak amacıyla yerine getirmektedirler (Chiaburu vd., 2013: 5).

Bir işletmede çalışanların işe yabancılaşmasına neden olan üç faktör yer almaktadır. Bunlar (Fettahlığlu, 2006:4; Chiaburu vd., 2014: 24; Zengin ve Kaygın, 2016:83; Şimşek vd., 2015:256; Kanten ve Ülker, 2014: 21; Kösterelioğlu, 2011: 51):

Örgütsel faktörler: İdarecilerin ilgisiz davranışları, otoriter yönetim, etkileşimci liderlik anlayışı, kurum içerisinde yaşanan olaylar, örgüt içerisinde sağlıklı bir iletişim ağının olmayışı, örgütün büyüklügüu, rol belirsizliği, rol çatışması, işte monotonluk, sabit bir işte sürekli çalışma, çalışma koşulları ve denetim uygulamalarından kaynaklanan rahatsızlıklar işe yabancılaşmaya neden olan örgütsel faktörler olarak görülmektedir.

Çevresel faktörler: Politika uygulamaları, sosyoekonomik faktörler, sendikal uygulamalar, kitle iletişim araçları, kentleşme ve sosyal değişim işe yabancılaşmayı etkileyen çevresel faktörler olarak görülmektedir.

Bireysel faktörler: çalışanların kurumlarından beklentileri ile kurumun sağladıkları arasındaki uyumsuzluklar, işletme içerisinde çalışanların kendilerini değersiz hissetmeleri, kişinin başarma ihtiyacı, kontrol odağı, çalışanlar ile idareciler arasında sağlıklı bir iletişim ağının olmaması işe yabancılaşmayı etkileyen bireysel faktörler olarak görülmektedir.

\section{3. İşten Ayrılma Niyeti}

İşgörenlerin örgüt içerisindeki çalışma yoğunluklarının aşırı boyutlarda olması, üst yönetim yetersiz olması, iş aile yaşamı çerçevesinde uyumsuzluklar olması, iş tatmininin düşüklüğü, aşırı stres altında çalışma, yetersiz ücret, düşük örgütsel bağlılık ve kariyer imkânlarının olmaması gibi olumsuz durumlar nedeni ile kişinin işi bırakma eğiliminde olmasıdır (Tekingündüz ve Kurtuldu, 2015: 1503). Rusbelt vd., (1988: 599) işten ayrılma niyetini, "İ̧̧görenlerin çalışma şartlarından memnun olmamaları nedeni ile sergilemiş oldukları aktif bir eylem" şeklinde ifade etmektedirler.

Çalışanlarda işi bırakma faaliyeti gerçekleşmeden önce işten ayrılma niyeti meydana gelmektedir (Tett ve Meyer, 1993:259; Teoman, 2007: 34). İşi bırakmaktan farklı olarak işten ayrılma niyeti ayrıca çalışanların işyerinde kalmak için kendilerini değerlendirdikleri süreç olarak da görülmektedir (Mobley, 1982: 10). İşten ayrılma niyeti aynı zamanda çalışanın bulunduğu iş yerinde çalışma ölçüsü olarak da değerlendirilmektedir (Orbay, 2008). Çalışanların işten ayrılma niyetini eyleme geçirip işi bırakma aşamasına gelmeleri için etkili olan üç unsur bulunmaktadır. Bunlar (Weisberg, 1994:4; Hom vd., 1992: 905; Şahin, 2011:277; Cotton ve Tuttle, 1986: 63-64):

Dış unsurlar: Çalışanların işi bırakmalarında etkili olan alternatif iş seçenekleri, işsizlik oranı, işten ayrıldıktan sonraki süreçte işsizlik ödeneği vb. durumlar dış unsurlar olarak değerlendirilmektedir.

Örgütsel unsurlar: Çalışanların işten ayrılma niyetleri sonrasında yönetim tarzındaki değişiklikler, ücretlendirmede ortaya çıkan faktörler ve ödüllendirme gibi faktörler örgütsel unsurlar olarak değerlendirilmektedir.

Kişisel unsurlar: Çalışanların kişilik yapısı, yaş durumu, ailesinin ekonomik durumu gibi faktörler, işten ayrılma niyetinin işi bırakma eylemine dönüşmesini etkileyen kişisel unsurlar olarak değerlendirilmektedir.

Çalışanlarda işten ayrılma niyetinin olması işletme ile işgören arasında bir çatışma olduğunun göstergesidir. İşten ayrılma niyeti sonrasında gerçekleşen işten ayrılmalar örgütler için istenmeyen bir durumu ifade etmektedir. İşten ayrılmaların çok olduğu işletmelerde işgücü devir oranı yüksek olmaktadır. İşgücü devir oranının yüksek olmasının nedenleri arasında; işçi işveren arasındaki politikaların uyumsuzluğu, denetim uygulamalarının personel üzerinde olumsuz etkisi, motivasyon uygulamalarındaki eksiklikler sayılmaktadır (Kumar ve Govindarajo, 2014:510).

\subsection{Alanyazın İncelemesi ve Araştırmanın Hipotezleri}

Algılanan örgütsel destek ile ilgili literatürde yapılan araştırmalar incelendiğinde; örgütsel vatandaşlık davranışı, lider üye etkileşimi, dönüşümsel liderlik, örgütsel adalet, esnek çalışma uygulamaları, iş zenginleştirme, iş güvenliği, iş performansı, bağlamsal performans, örgütsel bağlılık, iş aile dengesi ve öz yeterlilik ile örgütsel destek algısı arasında pozitif yönlü bir ilişki olduğu belirlenmiştir. Psikolojik sözleşme ihlalleri, iş aile çatışması, yöneticinin kötü niyeti, duygusal tükenme, iş stresi, tükenmişlik ve işe devamsızlık ile örgütsel destek algısı arasında negatif yönlü ilişki olduğu tespit edilmiştir. (Jawahar ve Carr, 2007; Chen vd., 2009; Rhoades ve Eisenberger, 2002; Eisenberger vd.,1986; Eisenberger vd.,1990; Miao ve Kim, 2010); Kurtessis vd., 2017; Lynch vd., 1999; Riggle vd., 2009; Kraimer vd., 2001; Settoon vd.,1996; Shanock ve Eisenberger, 2006; Muse vd., 2008)

Literatürde işe yabancılaşma ile ilgili yapılan araştırmalar neticesinde; çalışanların işe yabancılaşması ile iş performansları (Shantz vd., 2015), iş tatminleri (Yalçın ve Koyuncu, 2014), örgütsel vatandaşlık davranışları (Mendoza ve Zoghbi, 2008), örgütsel bağlılıkları (Sulu vd., 2010) ve iş yaşam kaliteleri (Uysaler, 2010; Efraty ve Sirgy, 1990; Kösterelioğlu, 2011; Erdem, 2014) azalmaktadır. Örgüt içerisinde işe yabancılaşma yaşayan çalışanların; üretkenlik karşıtı davranışlarında (Shantz vd., 2015), işten ayrılma niyetlerinde, örgütsel streslerinde, tükenmişlik duygularında (Chiaburu, 2014), örgütsel sessizliklerinde (Üstün ve Çamlıca, 2017) alkol kullanımlarında (Seeman ve Anderson, 1983: 60) ve sağlık problemlerinde (Shantz vd., 2014: 2529) artış görülmektedir. 
İşten ayrılma niyeti ile psikolojik sözleşme ihlali arasındaki ilişkisini araştıran çalışmalarda, psikolojik sözleşme ihlalinin çalışanların işten ayrılma niyetini artırdığı sonucuna ulaşmışlardır (Zao vd., 2007; Lee ve Faller, 2005; Robinson, 1996; Seçkin, 2011). Çalışanların işten ayrılma niyetleri ile iş yaşam kaliteleri arasındaki ilişkiye yönelik yapılan araştırmalarda negatif yönlü ilişki belirlenmiştir (Almalki vd, 2012; Mosadeghrad, 2013; Sezici, 2014; Y1ld1z, 2013; Demir, 2011; Çelik ve Öz, 2011).

Örgütsel destek algısı ve işe yabancılaşmaya yönelik yapılan araştırmalarda negatif yönlü ve anlamlı bir korelasyon olduğu tespit edilmiştir (Taştan vd., 2014; Özbek, 2011; Tanrıverdi ve Kılıç, 2016). Çalışkan ve Pekkan (2017) tarafından yapılan araştırmada, algılanan örgütsel desteğin çalışanların işe yabancılaşması üzerinde azaltıcı bir etkisi olduğu belirlenmiştir. İlgili yazında yapılan araştırmalar incelenerek, araştırmanın amacına uygun olarak aşağıdaki hipotezler geliştirilmiştir.

Hipotez 1: Algllanan örgütsel destek ile işe yabancılaşma arasında negatif yönlü ilişki bulunmaktadır.

Hipotez 2: Algllanan örgütsel destek, çalışanların işe yabancılaşması üzerinde etkilidir.

Örgütsel destek algısı ve işten ayrılma niyetine yönelik yapılan araştırmalarda, örgütsel destek ve işten ayrılma niyeti arasında negatif bir korelasyon olduğu belirlenmiştir (Wayne vd., 1997; Arokiasamy vd., 2010; Hui vd., 2007; Dawley vd., 2010; Maertz vd., 2007; Jawahar ve Hemmasi 2006; Yüksel, 2006; Turunç ve Çelik, 2010). İlgili yazında yapılan araştırmalar incelenerek, araştırmanın amacına uygun olarak aşağıdaki hipotezler geliştirilmiştir.

Hipotez 3: Algllanan örgütsel destek ile işten ayrlma niyeti arasında negatif yönlü ilişki bulunmaktadır.

Hipotez 4:Algılanan örgütsel destek, çalışanların işten ayrllma niyeti üzerinde etkilidir.

İşe yabancılaşma ve işten ayrılma niyeti ilişkisine yönelik yapılan araştırmalarda, işe yabancılaşma ile işten ayrılma niyeti arasında pozitif bir korelâsyon olduğu belirlenmiştir (Ayar, 2011; İnce Ayaydın, 2012; Atalay, 2013; Tuna ve Yeşiltaş, 2014; Ünsar ve Karahan, 2011). İlgili yazında yapılan araştırmalar incelenerek, araştırmanın amacına uygun olarak aşağıdaki hipotezler geliştirilmiştir.

Hipotez 5: Işse yabancılaşma ile işten ayrılma niyeti arasında pozitif yönlü ilişki bulunmaktadır.

Hipotez 6: Çalışanların işe yabancılaşma düzeyleri, işten ayrılma niyetleri üzerinde etkilidir.

\section{Metodoloji}

\subsection{Araştırmanın Amacı ve Yöntemi}

$\mathrm{Bu}$ çalışmada çalışanların örgütsel destek algıları ile işe yabancılaşma ve işten ayrılma niyetleri arasında ne tür bir korelâsyon olduğunun tespiti amaçlanmaktadır. Ayrıca, örgütsel destek algısının çalışanların işe yabancılaşması ve işten ayrılma niyetleri üzerindeki etkisi de bu çalışma ile tespit edilmeye çalışılmaktadır. Araştırmada belirlenen amaçları gerçekleştirmek için alan araştırması yapılmıştır Araştırmada verilerin toplanması için anket yönteminden yararlanılmıştır. Verilerin incelenmesinde istatistik paket programı olarak IBM SPSS 25. 0 paket programı kullanılmıştır. Araştırmada katılımcıların örgütsel destek algıları, işe yabancılaşma ve işten ayrılma niyetlerine yönelik görüşlerini ortaya koymak için betimsel istatistik analizi uygulanmıştır. Ayrıca, araştırmanın hipotezlerini değerlendirebilmek için korelâsyon analizi, basit doğrusal regresyon analizi gerçekleştirilmiştir.

\subsection{Araştırmanın Örneklemi ve Veri Toplama Aracı}

Araştırma Bursa İli Karacabey ilçesine görev yapan kamu çalışanlarına yönelik gerçekleştirilmiştir. Karacabey ilçesindeki kamu çalışanlarına 200 anket formu dağıtılmış, çalışanların iş yoğunluğundan dolayı anket formlarının 158'i araştırmaya elverişli bir şekilde uygulanabilmiştir. Araştırmada kullanılan anket dört kısımdan oluşmaktadır. İlk kısımda demografik özellikleri belirlemeye yönelik ifadeler bulunmaktadır. Anket formunun ikinci kısmında örgütsel destek algısına yönelik ifadeler, üçüncü kısımda işe yabancılaşmaya yönelik ifadeler ve dördüncü kısımda işten ayrılma niyetini belirlemeye yönelik ifadeler yer almaktadır.

Örgütsel Destek Alglsı Ölçeği: Ölçek Giray (2013) tarafından geliştirilmiş, Arslan (2018) tarafından yapılan araştırmada kullanılmış, geçerlilik ve güvenilirliği test edilmiştir. Ölçekte 11 ifade yer almaktadır. Ölçekte 2, 5, 6, 7,8 ve 10 . maddeler olumsuz ifadeler içerdiği için veri girişinde SPSS 25. 0 paket programına ters şekilde kodlanmıştır.

İşe Yabancılaşma Ölçeği: Ölçek Hirschfeld ve Field (2000: 791) tarafindan geliştirilmiştir. Ölçeğin Türkçe' ye uyarlanması, geçerliliği ve güvenilirliliği Kanten ve Ülker (2014) tarafından yapılmıştır. Ölçekte çalışanların işe yabancılaşma ile ilgili görüşlerini almak için 8 ifade kullanılmıştır.

İşten Ayrılma Niyeti Ölçeği: Ölçek, Wayne vd. (1997)’nin araştırmalarında kullandıkları ölçektir. Ölçeğin Türkçe uyarlaması, geçerlilik ve güvenilirliği Genç (2015) tarafından gerçekleştirilmiştir. Ölçekte katılımcıların işten ayrılma niyetini belirlemek amacıyla 5 ifade yer almaktadır.

Araştırmada 5'li likert tipinde ölçekler kullanılmıştır. Ölçeklerde yer alan ifadelerin puanlanmasında 1- Kesinlikle Katılmıyorum, 5-Kesinlikle Katılıyorum şeklindeki skaladan yararlanılmıştır.

\subsection{Araştırma Verilerinin Değerlendirilmesi}

Araştırmada kullanılan anketlerin çözümlenmesinde IBM SPSS 25. 0 istatistik programından yararlanılmış ve hipotezlerin analizinde $\% 95$ güven aralığı dikkate alınmıştır.

\subsubsection{Demografik Veriler}

Araştırmaya katılan işgörenlerin yaş dağılımları incelendiğinde $59(\% 37.3)$ kişi 25 yaş ve altı, 42 (\%26.6) kişi 26-31 yaş arası, 26 (\%16.5) kişi 32-37 yaş arası, 25 (\%15.8) kişi 38-43 yaş arası, 6 (\%3.8) kişi 44 ve üzeri yaş grubu içerisinde yer almaktadır. Katılımcıların 84 (\%53.2)' ü erkek, $74(\% 46.8)$ ' ü kadındır. Eğitim durumları incelendiğinde, ilköğretim mezunu 53 (\%33.5) kişi, lise mezunu 38 (\%24.1) kişi, önlisans mezunu 45 (\%28.5) kişi, lisans mezunu ise 22 (\%13.9) kişi bulunmaktadır. Anket uygulamasında katılanların 87 (\%55.1)' si evli, 71 (\%44.9)' i bekârdır. Çalışanların mesleki deneyimleri incelendiğinde 1-4 yıl arası çalışma deneyimi olan 87 (\%55.1) kişi, 5-8 yıl arası çalışma deneyimi olan 40 (\%25.3) kişi, 9-12 yıl arası 
çalışma deneyimi olan $13(\% 8.2)$ kişi, 13 yıl ve üzeri çalışma deneyimi olan ise $18(\% 11.4)$ kişi bulunmaktadır.

\subsubsection{Güvenilirlik Analizi ve Betimsel İstatistikler}

Araştırmaya katılan kamu çalışanlarının örgütsel destek algısına yönelik ifadelerini belirlemek için kullanılan ölçeğin güvenilirlik katsayısı 0.611, işe yabancılaşmaya yönelik görüşlerini belirlemek amacıyla kullanılan ölçeğin güvenilirlik katsayısı 0.862, işten ayrılma niyeti ölçek güvenilirlik katsayısı ise 0.832 'dir. Cronbach's Alpha değeri 0.60 ile 0.80 arasında ise ölçek oldukça güvenilir, 0.80 ile 1.00 arasında ise ölçek yüksek derecede güvenilirdir (Kalaycı, 2008: 405). Çalışmada kullanılan ölçekler güvenilir bulunmuştur.

Araştırmada kullanılan ölçeklere ilişkin tanımlayıcı istatistik bilgilere aşağıdaki tablolarda yer verilmektedir.

Tablo 1: Algılanan Örgütsel Desteğe İlişkin Betimsel İstatistik Tablosu

\begin{tabular}{|c|c|c|c|c|c|}
\hline $\begin{array}{l}\text { Algılanan Örgütsel } \\
\text { Destek Ölçeği }\end{array}$ & $\mathbf{N}$ & Min. & Max. & Ort. & S.S. \\
\hline $\begin{array}{l}\text { "Çalıştığım kurum } \\
\text { düşüncelerime önem } \\
\text { verir." }\end{array}$ & 158 & 1.00 & 5.00 & 2.73 & 1.28 \\
\hline $\begin{array}{l}\text { "Çalıştığım kurum işle } \\
\text { ilgili yakınmalarımı } \\
\text { dikkate almaz."* }\end{array}$ & 158 & 1.00 & 5.00 & 3.04 & 1.21 \\
\hline $\begin{array}{l}\text { "Çalıştığım kurum } \\
\text { benim iyiliğimi } \\
\text { gerçekten düşünür." }\end{array}$ & 158 & 1.00 & 5.00 & 3.37 & 1.06 \\
\hline $\begin{array}{l}\text { "Çalıştığım kurum işteki } \\
\text { başarılarımla gurur } \\
\text { duyar." }\end{array}$ & 158 & 1.00 & 5.00 & 3.64 & 1.10 \\
\hline $\begin{array}{l}\text { "Çalıştığım kurum beni } \\
\text { etkileyen kararlar } \\
\text { alırken, çıarlarımı } \\
\text { düşünmez."* }\end{array}$ & 158 & 1.00 & 5.00 & 2.56 & 1.18 \\
\hline $\begin{array}{l}\text { "Çalıştı̆̆ım kurumda } \\
\text { işimde gösterdiğim } \\
\text { ekstra çaba takdir } \\
\text { görmez."* }\end{array}$ & 158 & 1.00 & 5.00 & 2.70 & 1.18 \\
\hline $\begin{array}{l}\text { "Çalıştığım kurum } \\
\text { işimle ilgili } \\
\text { yapabileceklerin en } \\
\text { iyisini yapsam bile } \\
\text { bunun farkında } \\
\text { olmaz."* }\end{array}$ & 158 & 1.00 & 5.00 & 3.24 & 1.14 \\
\hline $\begin{array}{l}\text { "Çalıştığım kurum } \\
\text { benimle pek } \\
\text { ilgilenmez."* }\end{array}$ & 158 & 1.00 & 5.00 & 3.42 & 1.25 \\
\hline $\begin{array}{l}\text { "Çalıştı̆̆ım kurum onun } \\
\text { yararına olan } \\
\text { katkılarıma değer verir." }\end{array}$ & 158 & 1.00 & 5.00 & 3.42 & 1.32 \\
\hline $\begin{array}{l}\text { "Çalıştığım kurum } \\
\text { yükselmem için çok az } \\
\text { olanak sağlar."* }\end{array}$ & 158 & 1.00 & 5.00 & 2.80 & 1.09 \\
\hline $\begin{array}{l}\text { Çalıştığım kurum } \\
\text { işimden memnun olup } \\
\text { olmadığımla ilgilenir." }\end{array}$ & 158 & 1.00 & 5.00 & 3.37 & 1.10 \\
\hline $\begin{array}{l}\text { Algılanan Örgütsel } \\
\text { Destek (Genel) }\end{array}$ & 158 & 1.00 & 5.00 & 3.12 & 0.53 \\
\hline
\end{tabular}

*Ölçekte yer alan ifadeler ters kodlanmıştır.

Araştırmaya katılan çalışanların örgütsel destek algı düzeyi ortalamas1 3.12'dir. 5'li likert ölçeğine göre orta değerin üzerinde olduğu görülmektedir. Katılımcıların örgütsel destek algı düzeyleri ortanın üzerindedir. Ortalaması en yüksek örgütsel destek ifadesi "Çalıştığım kurum işteki başarılarımla gurur duyar.” şeklindedir. Ortalaması en düşük olan örgütsel destek ifadesi ise, ters kodlanmış olan "Çalıştığım kurum beni etkileyen kararlar alırken, çıkarlarımı düşünmez" ifadesidir.

Katılımcıların işe yabancılaşma ile ilgili görüşlerinin yer aldığı işe yabancılaşma ölçeği betimsel istatistik analizi sonuçları tablo 2'de gösterilmektedir.

Tablo 2: İşe Yabancılaşma Ölçeği Betimsel İstatistik Tablosu

\begin{tabular}{|c|c|c|c|c|c|}
\hline $\begin{array}{l}\text { İş Yabancılaşma } \\
\text { Ölçeği }\end{array}$ & $\mathbf{N}$ & Min. & Max. & Ort. & S.S. \\
\hline $\begin{array}{l}\text { "Bu kurumda neden } \\
\text { çalıştığımı bilmiyorum". }\end{array}$ & 158 & 1.00 & 5.00 & 2.56 & 1.43 \\
\hline $\begin{array}{l}\text { "Çalışma hayatımın } \\
\text { çoğunu anlamsız işlerle } \\
\text { geçiyorum." }\end{array}$ & 158 & 1.00 & 5.00 & 2.58 & 1.53 \\
\hline $\begin{array}{l}\text { "Ne kadar çok } \\
\text { çalışırsam çalışayım, } \\
\text { hiçbir zaman } \\
\text { amaçlarıma ulaşacağımı } \\
\text { düşünmüyorum." }\end{array}$ & 158 & 1.00 & 5.00 & 2.58 & 1.40 \\
\hline $\begin{array}{l}\text { "İşimle ilgili heyecan } \\
\text { duymuyorum." }\end{array}$ & 158 & 1.00 & 5.00 & 2.49 & 1.07 \\
\hline $\begin{array}{l}\text { "Çok fazla çalışmamın } \\
\text { bir anlamı yok, çünkü } \\
\text { sadece üst mevkilerde } \\
\text { bulunanlar daha fazla } \\
\text { kazanç elde edebiliyor." }\end{array}$ & 158 & 1.00 & 5.00 & 2.86 & 1.39 \\
\hline $\begin{array}{l}\text { "Sıradan işlerin, } \\
\text { yapmaya değmeyecek } \\
\text { kadar sıkıcı olduğunu } \\
\text { düşünüyorum." }\end{array}$ & 158 & 1.00 & 5.00 & 2.60 & 1.02 \\
\hline $\begin{array}{l}\text { "Bir fayda } \\
\text { sağlamayacağı için } \\
\text { işimde en iyi olmaya } \\
\text { çalışmıyorum." }\end{array}$ & 158 & 1.00 & 5.00 & 2.97 & 1.50 \\
\hline $\begin{array}{l}\text { "İşimi sevdiğim için } \\
\text { değil sadece para } \\
\text { kazanmak için } \\
\text { yapıyorum." }\end{array}$ & 158 & 1.00 & 5.00 & 2.78 & 1.32 \\
\hline $\begin{array}{l}\text { İş Yabancılaşma } \\
\text { (Genel) }\end{array}$ & 158 & 1.00 & 5.00 & 2.68 & 0.96 \\
\hline
\end{tabular}

Katılımcıların işe yabancılaşma düzeyleri ortalama değeri 2.68'dir. 5'li likert ölçeğine güre orta düzeyin altında bir işe yabancılaşma algısı vardır. İşe yabancılaşma ölçeği ifadelerinin tamamında katılım düzeyi orta değerin altındadır. Ortalaması en yüksek olan işe yabancılaşma ifadesi "Bir fayda sağlamayacağı için işimde en iyi olmaya çalışmıyorum” şeklinde iken, en düşük işe yabancılaşma ifadesi ise "İşimle ilgili heyecan duymuyorum" şeklindedir.

Araştırmaya katılan çalışanların işten ayrılma niyetine yönelik ifadeleri ve ortalama değerleri tablo 3 'de gösterilmektedir.

Tablo 3: İşten Ayrılma Niyeti Ölçeği Betimsel İstatistiği

\begin{tabular}{lccccc}
\hline $\begin{array}{l}\text { İşten Ayrılma Niyeti } \\
\text { Ölçeği }\end{array}$ & N & Min. & Max. & Ort. & S.S. \\
\hline $\begin{array}{l}\text { "Daha iyi bir iş bulur } \\
\text { bulmaz, bu kurumdan } \\
\text { ayrilacağım." }\end{array}$ & 158 & 1.00 & 5.00 & 2.83 & 1.41 \\
\hline $\begin{array}{l}\text { "Şu an çalıştı̆̆ım } \\
\text { kurumun dişında aktif } \\
\text { olarak iş arıyorum." }\end{array}$ & 158 & 1.00 & 5.00 & 2.88 & 1.45 \\
\hline
\end{tabular}




\begin{tabular}{|c|c|c|c|c|c|}
\hline $\begin{array}{l}\text { "İşimden ayrilmay1 } \\
\text { ciddi bir şekilde } \\
\text { düşünüyorum." }\end{array}$ & 158 & 1.00 & 5.00 & 2.96 & 1.39 \\
\hline $\begin{array}{l}\text { "Bu kurumdaki işimden } \\
\text { ayrılmayı sık sık } \\
\text { düşünüyorum." }\end{array}$ & 158 & 1.00 & 5.00 & 2.80 & 1.40 \\
\hline $\begin{array}{l}\text { "Sanırım önümüzdeki } \\
\text { beş yıl içinde hala bu } \\
\text { kurumda çalışıyor } \\
\text { olmayacağım." }\end{array}$ & 158 & 1.00 & 5.00 & 2.85 & 1.52 \\
\hline $\begin{array}{l}\text { İşten Ayrılma Niyeti } \\
\text { (Genel) }\end{array}$ & 158 & 1.00 & 5.00 & 2.86 & 1.11 \\
\hline
\end{tabular}

Katılımcıların işten ayrılma niyetine yönelik ortalama değerlerin yer aldığı betimsel istatistik verilerine göre, işten ayrılma niyeti ifadelerinin ortalama değeri 2.86 'dır. 5'li likert ölçeğine göre orta değerin altında işten ayrılma niyeti ortalaması olduğu görülmektedir. En yüksek işten ayrılma ifadesi "İşimden ayrılmayı ciddi bir şekilde düşünüyorum " şeklinde iken, en düşük işten ayrılma niyeti ifadesi ise "Daha iyi bir iş bulur bulmaz, bu kurumdan ayrılacağım" şeklindedir.

\subsubsection{Araştırma Hipotezlerinin Test Edilmesi}

Araştırma sonucunda elde edilen verilerin analize uygunluğuna, normal dağılım gösterip göstermediklerine ve analiz yöntemine karar verebilmek için KolmogorovSmirnov testi yapılmıştır. Analiz sonucunda Kurtosis ve Skewness değerlerinin -1 ve +1 değerleri arasında yer aldığ 1 belirlenmiştir. Hair vd. (2013), Kurtosis ve Skewness değerleri -1 ve +1 aralığında yer aldığında normal dağılıma göre analizler yapılabileceğini ifade etmektedirler.

Hipotez 1: Algllanan örgütsel destek ile işe yabancılaşma arasında negatif yönlü ilişki bulunmaktadır.

Hipotez 1'i test etmek için Pearson korelâsyon analizi gerçekleştirilmiştir. Analiz sonuçlarına tablo 4'de yer verilmektedir.

Tablo 4: Hipotez 1'e İlişkin Korelâsyon Analizi Tablosu

\begin{tabular}{lll}
\hline & & \multicolumn{1}{c}{$\begin{array}{c}\text { Isse Yabancılaşma } \\
\text { Pearson Korelâsyon Analizi }\end{array}$} \\
\hline & $\begin{array}{l}\text { Korelâsyon } \\
\text { Katsayısı }\end{array}$ & $\mathbf{- . 4 3 2}^{* *}$ \\
\cline { 2 - 3 } $\begin{array}{l}\text { Örgütsel } \\
\text { Destek Algısı } \\
\text { (Genel) }\end{array}$ & $\begin{array}{l}\text { Sig. (2- } \\
\text { kuyruklu) }\end{array}$ & .000 \\
\cline { 2 - 3 } & Kişi & 158
\end{tabular}

*Korelâsyon 0.05 düzeyinde anlamlıdır

**Korelâsyon 0.01 düzeyinde anlamlıdır.

Hipotez 1'i test etmek için gerçekleştirilen korelâsyon analizi neticesinde anlamlı sonuçlar elde edilmiştir. Algılanan örgütsel destek ile işe yabancılaşma arasında negatif yönlü ve anlamlı 0.432 oranında ve düşük düzeyde ilişki belirlenmiştir. Yöneticilerin çalışanlara yönelik uyguladıkları örgütsel destek faaliyetlerinin işe yabancılaşma oranlarını azalttığı görülmektedir. Korelâsyon analizi neticesinde Hipotez 1 'in desteklendiği görülmektedir.

Hipotez 2: Algılanan örgütsel destek, çalışanların işe yabancılaşması üzerinde etkilidir.
Çalışanların örgütsel destek algılarının işe yabancılama düzeyleri üzerindeki etkisini tespit etmek için basit doğrusal regresyon analizi uygulanmıştır. Analiz sonuçları tablo 5'de gösterilmektedir.

Tablo 5: Hipotez 2'ye İlişkin Basit Doğrusal Regresyon Analizi Tablosu

Bağımlı Değişken: İşe Yabancılaşma (Genel)

$\begin{array}{lllllll}\begin{array}{l}\text { Bağımsız } \\ \text { Değişken }\end{array} & \mathbf{R}^{2} & \mathbf{F} & \boldsymbol{\beta} & \mathbf{t} & \mathbf{p} & \mathbf{D}-\end{array}$

\begin{tabular}{llllcll}
\hline Orgütsel & & & & & & \\
Destek & .187 & 35.8 & & - & $\mathbf{. 0 0 0}^{*}$ & \\
Algisl & & $64^{* *}$ & -.779 & 5.989 & $*$ & \\
(Genel) & & & & & &
\end{tabular}

${ }^{*} p<0,05{ }^{*} p<0,01$ düzeyinde anlamlıdır.

Basit doğrusal regresyon analizi sonuçlarına göre, Durbin Watson test değerinin 2.354 olduğu belirlenmiş ve değişkenler arasında otokorelasyon olmadığı tespit edilmiştir. 1,5 - 2,5 arasında yer alan Durbin-Watson testi değeri, değişkenler arasında otokorelasyon olmadığını belirtmektedir (Öztürk, 2006: 267). Örgütsel destek algısının işe yabancılaşma üzerindeki etkisini belirlemek amacıyla oluşturulan regresyon modelinde $\mathrm{R}^{2}$ değerinin 0.187 olduğu tespit edilmiştir. Çalışanların işe yabancılaşma düşüncesinin 0.187'lik kısmı algılanan örgütsel destek ile açıklanmaktadır. Beta değerine bakıldığında, algılanan örgütsel destek işe yabancılaşmayı negatif yönlü ve 0.779 oranında etkilemektedir. Algılanan örgütsel destekteki 1 birimlik artışın işe yabancılaşma duygusunda 0.779 oranında azalmaya neden olduğu tespit edilmiştir. Basit doğrusal regresyon analizi neticesinde Hipotez 2'nin desteklendiği görülmektedir.

Hipotez 3: Algllanan örgütsel destek ile işten ayrılma niyeti arasında negatif yönlü ilişki bulunmaktadır.

Hipotez 3'ü test etmek için Pearson korelâsyon analizi uygulanmıştır. Analiz sonuçlarına tablo 6'da gösterilmektedir.

Tablo 6: Hipotez 3'e İlişkin Korelâsyon Analizi Tablosu

Pearson Korelâsyon Analizi

İşten Ayrılma Niyeti (Genel)

\begin{tabular}{lll}
\hline & $\begin{array}{l}\text { Korelâsyon } \\
\text { Katsayısı }\end{array}$ & .064 \\
\cline { 2 - 3 } $\begin{array}{l}\text { Örgütsel } \\
\text { Destek Algısı } \\
(\text { Genel })\end{array}$ & $\begin{array}{l}\text { Sig. (2- } \\
\text { kuyruklu) }\end{array}$ & .425 \\
\cline { 2 - 3 } & Kişi & 158 \\
\hline
\end{tabular}


*Korelâsyon 0.05 düzeyinde anlamlıdır $\quad$ **Korelâsyon 0.01 düzeyinde anlamlidir.

Katılımcıların örgütsel destek algıları ile işten ayrılma niyetleri arasındaki ilişkinin yönünü belirlemek için yapılan korelâsyon analizinde istatistiksel olarak anlamlı bir ilişki tespit edilememiştir. Korelâsyon analizi neticesinde Hipotez 3’ün desteklenmediği görülmektedir.

Hipotez 4: Algılanan örgütsel destek, çalışanların işten ayrılma niyeti üzerinde etkilidir.

Çalışanların örgütsel destek algılarının işten ayrılma niyetleri üzerindeki etkisini tespit etmek için basit doğrusal regresyon analizi yapılmıştır. Analize ilişkin bilgiler tablo 7'de gösterilmektedir.

Tablo 7: Hipotez 4'e İlişkin Basit Doğrusal Regresyon Analizi Tablosu

Bağımlı Değişken: İşten Ayrılma Niyeti (Genel)

\begin{tabular}{lcccccc}
\hline $\begin{array}{l}\text { Bağımsız } \\
\text { Değişken }\end{array}$ & $\mathbf{R}^{2}$ & $\mathbf{F}$ & $\boldsymbol{\beta}$ & $\mathbf{t}$ & $\mathbf{p}$ & $\mathbf{D}-\mathbf{W}$ \\
\hline $\begin{array}{l}\text { Örgütsel } \\
\begin{array}{l}\text { Destek Alglsl } \\
\text { (Genel) }\end{array}\end{array}$ & .004 & .641 & .133 & .801 & .425 & 1.636 \\
\hline
\end{tabular}

${ }^{*} p<0,05 * * p<0,01$ düzeyinde anlamlıdir.

Basit doğrusal regresyon analizi sonuçlarına göre, Durbin Watson test sonucunun 1.636 olduğu belirlenmiş ve değişkenler arasında otokorelasyon olmadığı tespit edilmiştir. Örgütsel destek algısının işten ayrılma niyeti üzerindeki etkisini tespit etmek için oluşturulan regresyon modelinde $p$ değeri (.425) 0.05 'den büyük olduğu için istatistiksel olarak anlamlı bir etkinin olmadığı belirlenmiştir. Basit doğrusal regresyon analizi neticesinde Hipotez 4'ün desteklenmediği görülmektedir.

Hipotez 5: Işse yabancılaşma ile işten ayrılma niyeti arasında pozitif yönlü ilişki bulunmaktadır.

Hipotez 5'i test etmek için Pearson korelâsyon analizi yapılmıştır. Analize ilişkin sonuçlar tablo 8 'de belirtilmektedir.

Tablo 8: Hipotez 5'e İlişkin Korelâsyon Analizi Tablosu

\begin{tabular}{llc}
\hline \multirow{2}{*}{ Pearson Korelâsyon Analizi } & $\begin{array}{c}\text { İşten Ayrılma Niyeti } \\
\text { (Genel) }\end{array}$ \\
\hline & $\begin{array}{l}\text { Korelâsyon } \\
\text { Katsayısı }\end{array}$ & $\mathbf{. 6 7 4 * *}$ \\
\cline { 2 - 3 } $\begin{array}{l}\text { İșe } \\
\begin{array}{l}\text { Yabancılaşma } \\
\text { (Genel) }\end{array}\end{array}$ & $\begin{array}{l}\text { Sig. (2- } \\
\text { kuyruklu) }\end{array}$ & .000 \\
\cline { 2 - 3 } & Kişi & 158
\end{tabular}

*Korelâsyon 0.05 düzeyinde anlamlıdır $\quad$ **Korelâsyon 0.01
düzeyinde anlamlıdır.

Çalışanların işe yabancılaşmaları ve işten ayrılma niyetleri arasındaki ilişkinin yönünü belirlemeye yönelik yapılan korelâsyon analizinde istatistiksel olarak anlamlı sonuçlar elde edilmiştir. İşe yabancılaşma ve işten ayrılma niyeti arasında pozitif yönlü 0.674 oranında ve orta düzeyde korelasyon olduğu belirlenmiştir. Çalışanların yaptıkları işe yabancılaşma duyguları arttıkça işten ayrılma niyetlerinde de artış olduğu görülmektedir. Korelâsyon analizi neticesinde Hipotez 5 'in desteklendiği görülmektedir.

Hipotez 6: Çalışanların işe yabancılaşma düzeyleri, işten ayrılma niyetleri üzerinde etkilidir.

Çalışanların işe yabancılaşma düzeylerinin işten ayrılma niyetleri üzerindeki etkisini tespit etmek için basit doğrusal regresyon analizi uygulanmıştır. Analiz sonuçları tablo 9'da gösterilmektedir.

Tablo 9: Hipotez 6'ya İlişkin Basit Doğrusal Regresyon Analizi Tablosu

Bağımlı Değişken: İşten Ayrılma Niyeti (Genel)

\begin{tabular}{|c|c|c|c|c|c|c|}
\hline $\begin{array}{l}\text { Bağımsız } \\
\text { Değişken }\end{array}$ & $\mathbf{R}^{2}$ & $\mathbf{F}$ & $\boldsymbol{\beta}$ & $\mathbf{t}$ & $\mathbf{p}$ & $\begin{array}{l}\text { D- } \\
\text { W }\end{array}$ \\
\hline $\begin{array}{l}\dot{\text { Isse }} \\
\text { Yabancilaş } \\
\text { ma (Genel) }\end{array}$ & $\begin{array}{c}.45 \\
4\end{array}$ & $\underset{* * *}{129.966}$ & $\begin{array}{c}.78 \\
0\end{array}$ & $\begin{array}{c}11.40 \\
0\end{array}$ & $\underset{*}{.000^{*}}$ & $\begin{array}{c}1.36 \\
1\end{array}$ \\
\hline
\end{tabular}

Basit doğrusal regresyon analizi sonuçlarına göre, Durbin Watson test değerinin 1.361 olduğu belirlenmiştir. Durbin Watson değeri, 1.5-2.5 aralığına yakın bir değerdedir ve otokorelasyon olmadiğ ${ }_{1}$ kabul edilebilir. İşe yabancılaşmanın işten ayrılma niyetine etkisini belirlemek amaciyla kurulan regresyon modelinde $\mathrm{R}^{2}$ değerinin 0.454 olduğu tespit edilmiştir. İşgörenlerin işten ayrılma niyetinin 0.454'lük kısmı işe yabancılaşma düzeyi ile açıklanmaktadır. Beta değeri incelendiğinde, işe yabancılaşma düzeyi işten ayrılma niyetini 0.780 oranında etkilemektedir. İşe yabancılaşma düzeyindeki 1 birimlik yükselişin işten ayrılma niyetinde 0.780 oranında yükselişe neden olduğu tespit edilmiştir. Basit doğrusal regresyon analizi neticesinde Hipotez 6'nın desteklendiği görülmektedir.

\section{Değerlendirme ve Sonuç}

$\mathrm{Bu}$ çalışmada örgütsel destek algısı ile çalışanların işe yabancılaşma ve işten ayrılma niyeti arasındaki ilişkiler incelenmektedir. Örgütsel destek algısının işe yabancılaşma ve işten ayrılma niyeti üzerindeki etkisi de bu çalışmanın amaçları arasında yer almaktadır. Yapılan araştırma sonucunda anlamlı neticeler elde edilmiştir. Araştırma Bursa ili Karacabey ilçesinde görev yapan kamu çalışanlarına yönelik gerçekleştirilmiştir. Araştırmaya tüm kamu çalışanlarının dâhil edilememesi, bu çalışmanın kısıtını oluşturmaktadır.

Çalışanların algıladıkları örgütsel desteğe ilişkin yapılan betimsel istatistik analizi sonucunda, orta değerin biraz üzerinde örgütsel destek algıları olduğu belirlenmiştir. Çalışanların işe yabancılaşma düzeylerine yönelik yapılan betimsel istatistik analizi neticesinde, işe yabancılaşma düzeylerinin orta değerin altında olduğu tespit edilmiştir. Araştırmaya katılan çalışanların işten ayrılma niyetini 
belirlemek amaciyla yapılan betimsel istatistik analizi sonucunda da, ișten ayrılma niyetinin orta değerin biraz altında olduğu görülmektedir.

Algılanan örgütsel destek ile işe yabancılaşma arasındaki ilişkiyi belirlemek için yapılan korelâsyon analizi neticesinde anlamlı sonuçlar elde edilmiştir. Algılanan örgütsel destek ile çalışanların işe yabancılaşması arasında negatif yönlü ilişki olduğu tespit edilmiştir. İşgörenlerin örgütsel destek algısı yükseldikçe işe yabancılaşma düzeylerinde azalma görülmektedir. Literatürde yapılan benzer araştırmalarda da işe yabancılaşma ve örgütsel destek alg1sı arasındaki ilişkinin negatif yönlü olduğu belirlenmiştir (Taştan vd., 2014; Tanrıverdi ve Kılıç, 2016; Özbek, 2011).

Algılanan örgütsel destek ve işgörenlerin işten ayrılma niyetleri arasındaki ilişkinin yönünü tespit etmek için gerçekleştirilen korelâsyon analizi neticesinde istatistiksel olarak anlamlı sonuç elde edilememiştir. Yapılan araştırmaya göre örgütsel destek algısı ve işten ayrılma niyeti arasında ilişki olmadığı görülmektedir. Literatürde yapılan benzer araştırmalarda örgütsel destek algısı ve işten ayrılma niyeti arasında negatif yönlü ilişki olduğu belirlenmiştir (Wayne vd., 1997; Arokiasamy vd., 2010; Hui vd., 2007; Dawley vd., 2010; Maertz vd., 2007; Jawahar ve Hemmasi 2006; Yüksel, 2006; Turunç ve Çelik, 2010).

İşgörenlerin işe yabancılaşma düzeyleri ve işten ayrılma niyetleri arasındaki ilişkinin yönünü belirlemek için gerçekleştirilen korelâsyon analizi neticesinde anlamlı sonuçlar elde edilmiştir. İşe yabancılaşma ve işgörenlerin ișten ayrılma niyeti arasında pozitif yönde ve yüksek düzeyde ilişki olduğu belirlenmiştir. Çalışanların işe yabancılaşma düzeyleri arttıkça işten ayrılma niyetlerinde de artış olduğu görülmektedir. Literatürde yapılan benzer araştırmalar incelendiğinde de, işe yabancılaşma ve işgörenlerin işten ayrılma niyetinin pozitif yönde ilişkili olduğu belirlenmiştir (Ayar, 2011; Ünsar ve Karahan, 2011; İnce Ayaydın, 2012; Atalay, 2013; Tuna ve Yeşiltaş, 2014).

Basit doğrusal regresyon modeli ile çalışanların algıladıkları örgütsel desteğin işe yabancılaşma düzeyini etkilediği belirlenmiştir. Örgütsel destek algısının işe yabancılaşma düzeyi üzerinde azaltıcı etkisinin olduğu belirlenmiştir. Çalışkan ve Pekkan (2017) yaptıkları benzer bir araştırmada, algılanan örgütsel desteğin çalışanların işe yabancılaşmasını negatif yönde etkilediğini belirlemişlerdir.

Örgütsel destek algısının işten ayrılma niyeti üzerindeki etkisini tespit etmek için kurulan basit doğrusal regresyon modelinde istatistiksel olarak anlaml bir netice elde edilememiştir. Regresyon modelinde algılanan örgütsel desteğin çalışanların işten ayrılma niyetlerinde herhangi bir etkisinin olmadığı belirlenmiştir.

İşe yabancılaşmanın çalışanların işten ayrılma niyetlerine olan etkisini belirlemek için oluşturulan basit doğrusal regresyon modeline göre istatistiksel olarak anlamlı neticeler elde edilmiştir. İşe yabancılaşma düzeyinin işten ayrılma niyetinin önemli bir belirleyicisi olduğu tespit edilmiştir. Çalışanların işe yabancılaşma düzeyi işten ayrılma niyetini pozitif yönde etkilemektedir.

Sonuç olarak, bu çalışma ile örgütsel destek algısının işe yabancılaşmayı etkilediği fakat işten ayrılma niyetine etkisinin olmadığı belirlenmiştir. İşe yabancılaşmanın ise işten ayrılma niyetine önemli bir etkisinin olduğu görülmektedir. İşletme yöneticilerinin çalışanların işe yabancılaşmalarını engellemek için örgütsel desteği arttırmaları gerekmektedir. İşe yabancılaşmış çalışanların mevcut kurumlarında çalışma isteklerinin az olduğu ve işi bırakma niyetinde oldukları anlaşılmaktadır. Sonraki çalışmalara öneri olarak, çalışanların işe yabancılaşmalarını ve işten ayrılma niyetini etkileyen diğer faktörlerin neler olduğu konusunda araştırma yapmaları tavsiye edilmektedir. Ayrıca örgütsel destek, işe yabancılaşma ve işten ayrılma niyetine yönelik ilișkilerin kamu ve özel sektör çalışanları arasında karşılaştırmalı olarak araştırılması da önerilmektedir. Bu çalışmanın hem iş dünyasına için hem de literatüre katkı sağlayacağı düşünülmektedir.

\section{Kaynakça}

Agarwal, S. (1993), Influence of formalization on role stress, organizational commitment and work alienation of salespersons: a cross-national comparative study, Journal of International Business Studies, 24(4), 715739.

Aiken, M. \& Hage, J. (1966), Organizational alienation: a comparative analysis, American Sociological Review, 31(4), 497-507.

Almalki, M. J, FitzGerald, G. \& Clark, M. (2012). The relationship between quality of work life and turnover intention of and turnover intention of primary health care nurses in Saudi Arabia. Primary Health Care Nurses in Saudi Arabia, BMC Health Services Research, 12, 314-325.

Arokiasamy, L., Marimuthu, M. \& Moorthy, M.K. (2010). A study on the perceived organisational support in the financial industry in Malaysia, a literature review. Interdisciplinary Journal of Contemporary Research in Business, 2 (7), 438-451.

Arslan, I. (2018), Sağlık çalışanlarında iş yaşam kalitesinin iş performansı üzerine etkisinde örgütsel desteğin aracılık rolü, Doktora Tezi, İstanbul: Okan Üniversitesi.

Aselage, J. \& Eisenberger. R. (2003). Perceived organizational support and psychological contracts: a theorical integration, Journal of Organizational Behavior, 24, 491-509.

Atalay, M. (2013). Kurumsal ataletin yabancılaşma ve işten ayrlma niyetine etkisi. Yüksek Lisans Tezi, Afyonkarahisar: Afyon Kocatepe Üniversitesi.

Ayar, S. (2011). Çă̆rı merkezlerindeki çalışma koşullarının örgüte yabancılaşma, devamsızllk ve işten ayrılma eğilimi üzerine etkileri: bir araştırma. Yüksek Lisans Tezi, İstanbul: Beykent Üniversitesi.

Banai, M. \& Reisel, W. D. (2007). The influence of supportive leadership and job characteristics on work alienation: a six - country investigation. Journal of World Business, 42(4), 463-476.

Çalışkan, A. \& Pekkan, N. Ü. (2017). Psikolojik sermayenin işe yabancılaşmaya etkisinde örgütsel desteğin aracılık rolü, İs ve İnsan Dergisi, 4(1), 17-33. 
Çelik, D. A. \& Öz, E. Ü. (2011). The effects of emotional dissonance and quality of work life perceptions on absenteeism and turnover intentions among Turkish call center employees. Social and Behavioral Sciences, 30, $2515-2519$.

Chen, Z. X., Eisenberger, R., Johnson, K.M., Sucharski, I.L. \& Aselage, J. (2009). Perceived organizational support and extra-role performance: which leads to which? Journal of Social Psychology, 149 (1), 119124.

Chiaburu, D. S., Diaz, I. \& De Vos A. (2013). Employee alienation: relationships with careerism and career satisfaction. Journal of Managerial Psychology, 28(1), 4-20.

Chiaburu, D. S., Thundiyil, T. \& Wang, J. (2014). Alienation and its correlates: a meta-analysis. European Management Journal, 32(1), 24-36.

Cotton, J.L. \& Tuttle, J.M. (1986). Employee turnover: a meta analysis and review with implications for research, The Academy of Management Review, 11(1), 55-70.

Dawley, D., Houghton, J.D. \& Bucklew, N.S. (2010). Perceived organizational support and turnover intention: the mediating effects of personal sacrifice and job fit. The Journal of Social Psychology, 150 (3), 238-257.

Demir, M. (2011). İşgörenlerin çalışma yaşamı kalitesi algılamalarının işte kalma niyeti ve işe devamsızlık ile ilişkisi. Ege Akademik Bakış Dergisi, 11 (3), 453464.

Efraty, D. \& Sirgy, M. J. (1990). The effects of quality of working life (QWL) on employee behavioral responses. Social Indicators Research, 22 (1), 31-47.

Eisenberger, R., Fasolo, P. \& Davis-LaMastro, V. (1990). Perceived organizational support and employee diligence, commitment, and innovation. Journal of Applied Psychology, 75, 51-59.

Eisenberger, R., Huntington, R., Hutchison, S. \& Sowa, D. (1986). Perceived organizational support, Journal of Applied Psychology, 71, 500-507.

Erdem, M. (2014). İş yaşamı kalitesinin işe yabancılaşmayı yordama düzeyi. Kuram ve Uygulamada Eğitim Bilimleri, 4(2), 519-544.

Fettahlığlu, T. (2006), Örgütlerde yabancılaşmanın yönetimi: Kahramanmaraş özel işletme ve kamu kuruluşlarında karşılaştırmalı bir araştırma, Yüksek Lisans Tezi, Kahramanmaraş: Kahramanmaraş Sütçü İmam Üniversitesi.

Genç, E. (2015). İş yaşam kalitesi ve işe yabancılaşmanın işten ayrlma niyeti üzerine etkisi: hizmet sektöründe bir uygulama, Yüksek Lisan Tezi, Hatay: Mustafa Kemal Üniversitesi.

Hair, J. F., Black, W. C., Babin, B. J., Anderson, R. E. \& Tatham, R. L. (2013). Multivariate data analysis, New Jersey: Pearson Education.
Hirschfeld, R. R. \& Feild, H. S. (2000). Work centrality and work alienation: distinct aspects of a general commitment to work. Journal of Organizational Behavior, 21, 789-800.

Hom, P.W., Caranikas-Walker, F., Prussia, G.E. \& Griffeth, R.W.(1992). A meta-analytical structural equations analysis of a model of employee turnover, Journal of Applied Psychology, 77(6), 890-909.

Hui, C., Wong, A. \& Tjosvold, D. (2007). Turnover intention and performance in China: the role of positive affectivity, Chinese values, perceived organizational support and constructive controversy. Journal of Occupational and Organizational Psychology, 80, 735-751.

İnce Ayaydın, Ç. (2012). Isşyerinde psikolojik şiddetin iş tatmini, işe yabancllaşma ve işten ayrılma niyeti ile ilişkisi. Yüksek Lisans Tezi, Gümüşhane: Gümüşhane Üniversitesi.

Jawahar, I. M. \& Carr, D. (2007). Conscientiousness and contextual performance: the compensatory effects of perceived organizational support and leader-member exchange. Journal of Managerial Psychology, 22 (4), 330-349.

Jawahar, I.M. \& Hemmasi, P. (2006). Perceived organizational support for women's advancement and turnover intentions the mediating role of job and employer satisfaction. Women in Management Review, 21 (8), 643-661.

Kalaycı, Ş. (2008). SPSS uygulamalı çok değişkenli istatistik teknikleri. Ankara: Asil Yayın Dağıtım.

Kanten, P. \& Ülker, F. (2014). Yönetim tarzının üretkenlik karşıtı iş davranışlarına etkisinde işe yabancılaşmanın arac1lık rolü. Muğla Sıtkı Koçman Üniversitesi Sosyal Bilimler Enstitüsü Dergisi, 32, 16-40.

Kaplan, M., (2010) Otel işletmelerinde etiksel iklim ve örgütsel destek algllamalarının örgütsel bağlılık üzerindeki etkisi: Kapadokya örneği, Doktora Tezi, Konya: Selçuk Üniversitesi.

Kerse, G., \& Karabey, C. N. (2017). Algılanan örgütsel desteğin örgütsel özdeşleşmeye etkisi: örgütsel sinizmin aracı rolü. MANAS Sosyal Araştırmalar Dergisi, 6(4), 375-398.

Kösterelioğlu, M. A. (2011). Ilköğretim okulu ögretmenlerinin iş yaşam kalitesi ile işe yabancılaşması arasındaki ilişki. Doktora Tezi, Bolu: Abant İzzet Baysal Üniversitesi.

Kraimer, M.L. Wayne S.J. \& Jaworski, R.A. (2001). Sources of support and expatriate performance: the mediating role of expatriate adjustment, Personnel Psychology, 54, 71-99.

Kumar, D. \& Govindarajo, N. S. (2014). Instrument development intention to stay instrument (ISI). Asian Social Science, 10(12), 149-169.

Kurtessis, J. N., Eisenberger, R., Ford, M. T., Buffardi, L. C., Stewart, K. A., \& Adis, C. S. (2017). Perceived organizational support: a meta-analytic evaluation of 
organizational support theory, Journal of Management, 43(6), 1854-1884.

Lee, G.J. \& Faller, N. (2005), Transactional and relational aspects of the psychological contracts of temporary workers, South African Journal of Psychological, 35(4), 831-847.

Lynch, P.D., Eisenberger, R. \& Armeli, S. (1999). Perceived organizational support: inferior versus superior performance by wary employees. Journal of Applied Psychology, 84 (4), 467-483.

Maertz, C.P., Jr., Griffeth, R.W., Campbell, N.S. \& Allen, D.G. (2007). The effects of perceived organizational support and perceived supervisor support on employee turnover. Journal of Organizational Behavior, 28 (8), 1059-1075.

Mendoza, M. J. S. \& Zoghbi M.L.P. (2008). The impact of work alienation on organizational citizenship behavior in the Canary Islands. International Journal of Organizational Analysis, 15(1), 56-76.

Meyer, J. P., Allen, N. J.\& Gellatly, I. R., (1990). Affective and continuance commitment to the organization: evaluation of measures and analysis of concurrent and time-lagged relations, Journal of Applied Psychology, 75(6), 710- 720.

Miao, R. \& Kim, H.G. (2010). Perceived organizational support, job satisfaction and employee performance: a Chinese empirical study. Journal of Service Science and Management, 3, 257-264.

Mobley, W.H. (1982). Employee turnover: causes, consequences and control, Massachusetts: AddisonWesley Inc.

Mosadeghrad, A. M. (2013). Quality of working life and turnover intentions: implications for nursing management. International Journal of Research in Nursing, 4 (2), 47-54.

Muse, L., Harris, S.G., Giles, W.F. \& Feild, H.S. (2008). Work-life benefits and positive organizational behavior: is there a connection? Journal of Organizational Behavior, 29, 171-192.

Nair, N. \& Vohra, N. (2012). The concept of alienation: towards conceptual clarity. International Journal of Organizational Analysis, 20(1), 25-50.

Orbay, N.T. (2008). Hastanelerde hemşirelerin işte kalma ve işten ayrlma niyetlerini etkileyen faktörlerin belirlenmesi, Yüksek Lisans Tezi, İstanbul: Haliç Üniversitesi.

Özbek, M.F. (2011). Örgüt içerisindeki güven ve işe yabancılaşma ilişkisinde örgüte uyum sağlamanın aracı rolü, Süleyman Demirel Üniversitesi İktisadi ve İdari Bilimler Fakültesi Dergisi, 16(1), 231-248.

Özdevecioğlu, M. (2003). Algılanan örgütsel destek ile örgütsel bağlılık arasındaki ilişkilerin belirlenmesine yönelik bir araștırma. Dokuz Eylül İktisadi ve İdari Bilimler Fakültesi Dergisi, 18(2), 113- 130.

Öztürk, E. (2006). Çoklu doğrusal regresyon modeli, İçinde: Ş.Kalaycı (Ed). SPSS uygulamalı çok değişkenli istatistik teknikleri (s.259-269). Ankara: Asil Yayın Dağıtım.

Rhoades, L. \& Eisenberger, R. (2002). Perceived organizational support: a review of the literature, Journal of Applied Psychology, 87(4), 698-714.

Riggle, R. J., Edmondson, D. R. \& Hansen, J. D. (2009). A meta-analysis of the relationship between perceived organizational support and job outcomes: 20 years of research. Journal of Business Research, 62(10), 1027-1030.

Robinson, S.L. (1996). Trust and breach of the psychological contract, Administrative Science Quarterly, 41(4), 574-599.

Rottinghaus, P.J., Hees, C.K. \& Conrath, J.A. (2009). Enhancing job satisfaction perspectives: combining Holland themes and basic interests, Journal of Vocational Behavior, 75,139-151.

Rusbelt, C.E., Farrell, D., Rogers, G. \& Mainous, A. G. (1988). Impact of exchange variables on exit, voice, loyalty and neglect: an integrative model of responses to decline job satisfaction, Academy of Management Journal, 31(2), 599-627.

Şahin, F. (2011). Lider-üye etkileşimi ile işten ayrılma niyeti arasındaki ilişki üzerinde cinsiyetin etkisi, Ege Akademik Bakış Dergisi, 11(2), 277-288.

Schaffer, M. A. \& Harrison, D. A. (2001). Struggling for balance amid turbulence on international assignments: Work-family conflict, support, and commitment. Journal of Management, 27(1), 99-121.

Seçkin, Z. (2011), Psikolojik sözleşme, Konya: Atlas Akademi Yayıncılık.

Seeman, M. \& Anderson, C. S. (1983). Alienation and alcohol: the role of work, mastery, and community in drinking behavior. American Sociological Review, 48(1), 60-77.

Settoon, R.P., Bennett N. \& Liden, R.C. (1996). Social exchange in organizations: perceived organizational support, leader-member exchange and employee reciprocity. Journal of Applied Psychology, 81 (3), 219-227.

Sezici, E. (2014). Çalışma yaşamı kalitesi, işyerinde sapkın davranış ve işten ayrılma eğilimi ilişkisi. Dumlupınar Üniversitesi Sosyal Bilimler Dergisi, 41, 235-246.

Shanock, L.R. \& Eisenberger, R. (2006). When supervisors feel supported: relationships with subordinates' perceived supervisor support, perceived organizational support and performance. Journal of Applied Psychology, 91 (3), 689-695

Shantz, A., Alfes, K. \& Truss, C. (2014). Alienation from work: Marxist ideologies and twenty-first-century practice. The International Journal of Human Resource Management, 25(18), 2529-2550.

Shantz, A., Alfes, K., Bailey, C. \& Soane, E. (2015). Drivers and outcomes of work alienation: reviving a concept. Journal of Management Inquiry, 24(4), 382-393. 
Şimşek, M.Ş., Akgemici T. \& Çelik A. (2015), Davranış bilimlerine giriş ve örgütlerde davranış, Konya: Eğitim Yayınevi.

Sulu, S., Ceylan, A. \& Kaynak, R. (2010). Work alienation as a mediator of the relationship between organizational injustice and organizational commitment: implications for healthcare professionals. International Journal of Business and Management, 5(8), 27-38.

Tanrıverdi, H. \& Kılıç, N. (2016). Algılanan Örgütsel Destek ve Örgütsel Yabancılaşma Arasındaki İlişkinin İncelenmesi, Hacettepe Üniversitesi Sosyolojik Araștırmalar E-Dergisi, 1(1),1-18.

Taştan, S., İşci, E. \& Arslan, B. (2014). Örgütsel destek algısının işe yabancılaşma ve örgütsel bağlılığa etkisinin incelenmesi: İstanbul özel hastanelerinde bir çalışma, Pamukkale Üniversitesi Sosyal Bilimler Enstitüsü Dergisi, 19, 121-138.

Tekingündüz, S. \& Kurtuldu, A. (2015). İşten ayrilma niyeti, iş tatmini, örgütsel bağlılık, liderlik ve iş stresi arasındaki ilişkilerin analizi: bir hastane örneği, International Journal of Human Sciences, 12(1), 1501- 1517.

Teoman, D. D. (2007). Performans Değerlendirme Sürecinde Oluşan Adalet Algısı, Bu Algının İç, Dışve Sosyal Ödüllerle Olan İlişkisinin İşten Ayrlma Niyeti'ne Olan Etkisi, Yüksek Lisans Tezi, İstanbul: İstanbul Üniversitesi.

Tett, R.P. \& Meyer, J.P. (1993). Job satisfaction, organizational commitment, turnover intention, and turnover: path analyses based on meta analytic findings, Personnel Psychology, 46, 259-293.

Tuna, M. \& Yeşiltaş M. (2014). Etik iklim, işe yabancılaşma ve örgütsel özdeşleşmenin işten ayrılma niyeti üzerindeki etkisi: otel işletmelerinde bir araştırma. Turizm Araştırmaları Dergisi, 25 (1), 105-117.

Turunç, Ö. \& Çelik, M. (2010). Algılanan örgütsel desteğin çalışanların iş-aile, aile-iş çatışması, örgütsel özdeşleşme ve işten ayrılma niyetine etkisi: savunma sektöründe bir uygulama. Atatürk Üniversitesi Sosyal Bilimler Enstitüsü Dergisi, 14 (1), 209-232.

Ünsar, A. S. \& Karahan, D. (2011). Yabancılaşmanın ișten ayrılma eğilimine etkisini belirlemeye yönelik bir alan araştırması. Selçuk Üniversitesi İktisadi ve İdari Bilimler Fakültesi Sosyal ve Ekonomik Araştırma Dergisi, 21, 361-378.

Üstün, F. \& Çamlıca, K. (2017). Örgütsel yabancılaşmanın örgütsel sessizlik üzerindeki ilişkide iş tatmininin aracılık etkisi: Nevşehir ili kamu çalışanları örneği. Journal of Recreation and Tourism Research, 4(3), 93-105.

Uysaler, A. L. (2010). Örgütsel yabancllaşmanın örgütsel bağglılık, iş tatmini ve işten ayrılma eğilimi ile bağlantısı ve yabancılaşma yönetimi. Yüksek Lisans Tezi,İstanbul: Gebze Teknik Üniversitesi.

Wayne, S. J., Shore, L.M. \& Liden R.C. (1997). Perceived organizational support and leader-member exchange: a social exchange perspective. Academy of Management Journal, 40 (1), 82-111

Weisberg, J. (1994). Measuring workers' burnout and intention to leave, International Journal of Manpower, 15(1), 4-14.

Yalçın, İ. \& Koyuncu, S.C. (2014). Örgütsel yabancılaşma olgusunun iş tatmini üzerine etkisi: Niğde ilinde bir araştırma. KMÜ Sosyal ve Ekonomik Araştırmalar Dergisi, 16(26), 86-94.

Yıldız, S. M. (2013). Spor ve fiziksel etkinlik işletmelerinde iş yaşam kalitesinin çalışanların işten ayrılma niyetine etkisi. Ege Akademik Bakış Dergisi, 13 (3), 317-324

Yüksel, İ. (2006). Örgütsel destek algısı ve belirleyicilerinin işten ayrılma eğilimi ile ilişkisi. I. Ü. Işsletme Fakültesi Dergisi, 35 (1), 7-32.

Zagenczyk, T. J. (2006). A social influence analysis of perceived organizational support, Doctoral Dissertation, Pittsburgh: University of Pittsburgh.

Zengin, Y. \& Kaygın, E. (2016). İşyerinde psikolojik tacizin (mobbing) örgütsel yabancılaşma ilişkisini belirlemeye yönelik bir araştırma. International Journal of Academic Value Studies, 2(5), 76-98.

Zhao, H., Wayne, S. J., Glibkowski, B. C. \& Bravo, J. (2007), The impact of psychological contract breach on work-related outcomes: a meta- analysis, Personnel Psychology, 60, 647-680. 